\title{
Origin of Angiosperms and Their Diversification in the Cretaceous
}

\author{
Xin Wang \\ State Key Laboratory of Palaeobiology and Stratigraphy, Nanjing Institute of Geology and Palaeontology and Center for \\ Excellence in Life and Paleoenvironment, Chinese Academy of Sciences, Nanjing, China \\ Email: xinwang@nigpas.ac.cn
}

How to cite this paper: Wang, X. (2019) Origin of Angiosperms and Their Diversification in the Cretaceous. Open Journal of Geology, 9, 577-580.

https://doi.org/10.4236/ojg.2019.910046

Received: August 15, 2019

Accepted: September 20, 2019

Published: September 23, 2019

Copyright (c) 2019 by author(s) and Scientific Research Publishing Inc. This work is licensed under the Creative Commons Attribution International License (CC BY 4.0).

http://creativecommons.org/licenses/by/4.0/

\section{(c) (i) Open Access}

\begin{abstract}
The dominating hypothesis stated that angiosperms originated in the Early Cretaceous, there were no pre-Cretaceous angiosperms, and carpels (the basic units of gynoecium) were derived from former megasporophylls bearing ovules/seeds along their margins through longitudinally folding and enrolling. However, there are increasing evidences of pre-Cretaceous angiosperms, the assumed megasporophyll actually does not exist, and the Cretaceous-only history of angiosperms appears much shorter than suggested by molecular clocks. Here I will integrate new knowledge of living and fossil plants to give a plausible explanation for the origin and early evolution of angiosperms. Several lines of evidence indicate that the ancestor of angiosperms may well have been present in the Triassic. The former gap between angiosperms and gymnosperms is artificial. Some Triassic fossils playing a role intermediate between angiosperms and gymnosperms seem to favor the Unifying Theory.
\end{abstract}

\section{Keywords}

Jurassic, Triassic, Angiosperms, Origin, Evolution, Fossils, Unifying Theory

\section{Introduction}

Under the light of the newly discovered Bennettitalean fossils with bisexual organs [1], the Traditional Theory advanced by Arber and Parkin [2] thought that Magnoliaceae was the basalmost group in angiosperms, and their conduplicate carpels were derived from former megasporophylls bearing ovules along their margins. Surprisingly and embarrassingly, today many botanists have to admit that they have no idea on the homology of carpels. The history of angiosperms was thought no earlier than the Cretaceous [3], although molecular clocks suggested that the origin of angiosperms must be much older [4]. Therefore, this 
mainstream thought becomes shaky in front of recent progress made in palaeobotany as well as botany.

\section{Fossil Record of Early Angiosperms}

Needless to say, there are abundant angiosperms in the Early Cretaceous, including Chaoyangia, Archaefructus, Sinocarpus, Callianthus, Baicarpus, Liaoningfructus, Nothodichocarpum from the Yixian Formation [5]. Slightly younger macrofossils from South America [6] demonstrate notable diversity of angiosperms. Mesofossils from Europe and North America embody the diversification of angiosperms in the early-middle Cretaceous [3]. At the beginning of the Late Cretaceous, Eudicots (accounting for $70 \%$ species diversity in living angiosperms) started playing a major and increasingly important role in the ecosystem [7]. This rapid diversification was erroneously called an "abominable mystery" by Darwin.

So far angiosperms in the Jurassic include Schmeissneira, Xingxueanthus, Solaranthus, Euanthus, Yuhania, Juraherba, and Nanjinganthus [5] [8]. Nanjinganthus with more than two hundred specimens convincingly suggest 1) flowers have occurred in the Early Jurassic, 2) some angiosperms may have flourished in certain niches although still rare and ecologically minor in the vegetation.

Currently there are little traces of bona fide angiosperms in the Triassic. However, Nubilora from the Upper Triassic of Yunnan [5], although not a bona fide angiosperm, demonstrate a great resemblance to angiosperms, in term of ovule-enclosing. Pollen grains from the Middle Triassic [9] are hard to be distinguished from those of angiosperms.

\section{Bridging the Gap between Angiosperms and Gymnosperms}

More than two decades ago, studies on functions genes have suggested that the ovules are parts independent from others [10]. Studies on the assumed ancestral Magnoliaceae revealed that each of their carpels comprises an ovuliferous branch and a subtending leaf [11] [12]. Given this Bau-plan of carpels, it is easy to see that lateral appendages in some former controversial Mesozoic "conifers" (such as Palissya, Metridiostrobus, Stachyotaxus [13] [14] [15]) and some living conifers (e.g. Juniperus) seem to stand between typical conifers and Magnoliaceae: all are characterized by subtending bract/leaf with an axillary branch bearing ovules. Given the new knowledge of magnoliaceous carpels [11] [12] and their resemblance to these Mesozoic fossil taxa, it requires little imagination that carpels characteristic of angiosperms may come into existence when the subtending leaf fully encloses the ovules in its axil.

\section{Conclusion}

Increasing fossil evidence suggests that angiosperms originated earlier than assumed, mostly likely in the Triassic ( $>200 \mathrm{Ma}$ ), a conclusion in line with mole- 
cular clocks. Angiosperms have undergone a long time of little-understood development and extinction in the Jurassic. They underwent two episodes of diversification in the Cretaceous.

\section{Acknowledgements}

This research is supported by the Strategic Priority Research Program (B) of Chinese Academy of Sciences (Grant No. XDB26000000), National basic Research Program of China (973 Program 2012CB821901), and National Natural Science Foundation of China $(41688103,91514302,41572046)$. This is a contribution to UNESCO/IUGS/IGCP 679 project.

\section{Conflicts of Interest}

The author declares no conflicts of interest regarding the publication of this paper.

\section{References}

[1] Wieland, G.R. (1906) American Fossil Cycads. The Wilkens Sheiry Printing Co., Washington DC.

[2] Arber, E.A.N. and Parkin, J. (1907) On the Origin of Angiosperms. Journal of the Linnean Society of London, Botany, 38, 29-80. https://doi.org/10.1111/j.1095-8339.1907.tb01074.x

[3] Friis, E.M., Crane, P.R. and Pedersen, K.R. (2011) The Early Flowers and Angiosperm Evolution. Cambridge University Press, Cambridge. https://doi.org/10.1017/CBO9780511980206

[4] Barba-Montoya, J., Reis, M., Schneider, H., Donoghue, P.C.J. and Yang, Z. (2018) Constraining Uncertainty in the Timescale of Angiosperm Evolution and the Veracity of a Cretaceous Terrestrial Revolution. New Phytologist, 218, 819-834. https://doi.org/10.1111/nph.15011

[5] Wang, X. (2018) The Dawn Angiosperms. Springer, Berlin, 1-407. https://doi.org/10.1007/978-3-319-58325-9

[6] Coiffard, C., Mohr, B.A.R. and Bernardes-de-Oliveira, M.E.C. (2014) Hexagyne Philippiana gen. et sp. nov., a Piperalean Angiosperm from the Early Cretaceous of Northern Gondwana (Crato Formation, Brazil). Taxon, 63, 1275-1286. https://doi.org/10.12705/636.17

[7] Liu, Z.J., Huang, D., Cai, C. and Wang, X. (2018) The Core Eudicot Boom Registered in Myanmar Amber. Scientific Reports, 8, Article No. 16765. https://doi.org/10.1038/s41598-018-35100-4

[8] Fu, Q., Diez, J.B., Pole, M., Ávila, M.G., Liu, Z.J., Chu, H., Hou, Y.M., Yin, P.F., Zhang, G.Q., Du, K.H. and Wang, X. (2018) An Unexpected Noncarpellate Epigynous Flower from the Jurassic of China. eLife, 7, e38827. https://doi.org/10.7554/eLife.38827

[9] Hochuli, P.A. and Feist-Burkhardt, S. (2013) Angiosperm-Like Pollen and Afropollis from the Middle Triassic (Anisian) of the Germanic Basin (Northern Switzerland). Frontiers in Plant Science, 4, 344. https://doi.org/10.3389/fpls.2013.00344

[10] Skinner, D.J., Hill, T.A. and Gasser, C.S. (2004) Regulation of Ovule Development. Plant Cell, 16, S32-S45. https://doi.org/10.1105/tpc.015933 
[11] Liu, W.Z., Hilu, K. and Wang, Y.L. (2014) From Leaf and Branch into a Flower: Magnolia Tells the Story. Botanical Studies, 55, 28.

https://doi.org/10.1186/1999-3110-55-28

[12] Zhang, X., Liu, W. and Wang, X. (2017) How the Ovules Get Enclosed in Magnoliaceous Carpels. PLoS ONE, 12, e0174955.

https://doi.org/10.1371/journal.pone.0174955

[13] Schweitzer, H.J. (1963) Der weibliches Zapfen von Pseudovoltzia liebeana und seine Bedeutung fuer die Phylogenie der Koniferen. Paläontographica B, 113, 1-29.

[14] Pattemore, G.A., Rigby, J.F. and Playford, G. (2014) Palissya: A Global Review and Reassessment of Eastern Gondwanan Material. Review of Palaeobotany and Palynology, 210, 50-61. https://doi.org/10.1016/j.revpalbo.2014.08.002

[15] Wang, Z. (2012) A Bizarre Palissya Ovulate Organ from Upper Triassic Strata of the Zixing Coal Field, Hunan Province, China. Chinese Science Bulletin, 57, 1169-1177. https://doi.org/10.1007/s11434-012-4975-8 